\title{
MOŻLIWOŚCI PREZENTACJI I UPOWSZECHNIANIA SZTUKI OSÓB Z NIEPEŁNOSPRAWNOŚCIĄ INTELEKTUALNĄ
}

Streszczenie: Artykuł ukazuje, w jaki sposób właściwie prowadzone działania ekspozycyjne oraz edukacyjne związane z twórczością osób z niepełnosprawnością intelektualną prowadzą do zmiany ich społecznego wizerunku i włączenia w świat pełnoprawnych twórców kultury i sztuki. Posłużono się w nim przykładem Działu Plastyki Nieprofesjonalnej Muzeum Śląskiego w Katowicach jako instytucji aktywnie zaangażowanej w działalność na rzecz promowania twórczości osób z niepełnosprawnością intelektualną jako sztuki.

Słowa kluczowe: niepełnosprawność intelektualna, sztuka, plastyka nieprofesjonalna, muzeum

\section{Wstęp}

Sztuka „jest [...] pozostawianiem śladów swojego istnienia - dla większości w kręgu najbliższych, dla części w środowisku lokalnym, a dla nielicznych w szerszej przestrzeni" (Kosakowski 2006, s. 24).

Wśród osób z niepełnosprawnością intelektualną odnaleźć można takie, których sztuka pozostawia ślady w szerszej przestrzeni; doceniania jest ze względu na swoje walory artystyczne. Podziwia się jej niepowtarzalność, świeżość, szczerość i bezkompromisowość (Pawlik 2012, s. 181). Jednak aby ich działalność artystyczna mogła być postrzegana jako sztuka, musiała dokonać się zasadnicza zmiana w ujmowaniu zjawiska samej niepełnosprawności. Ewolucja dokonuje się w kilku aspektach:

- od przedmiotowej do podmiotowej wizji człowieka niepełnosprawnego;

- od przywiązania do stygmatyzującego ilorazu inteligencji do oceny faktycznych możliwości osoby z niepełnosprawnością intelektualną;

- od segregacji i wykluczania do udzielania pomocy i wsparcia w zakresie włączania osoby niepełnosprawnej intelektualnie do środowiska społecznego;

- od zupełnej zależności od opiekuna do wdrażania do samostanowienia. 
Proces ten jest dynamiczny, wciąż jesteśmy świadkami jakościowych zwrotów w myśleniu o niepełnosprawności i postrzeganiu osób niepełnosprawnych.

Ze zmianą wymienionych perspektyw wiąże się konieczność uwolnienia od instrumentalnego podejścia do twórczości jako narzędzia podporządkowanego terapii, rehabilitacji oraz diagnozie osób z niepełnosprawnością (Gajdzica 2011, s. 12). Należy również jasno oddzielić zjawisko sztuki osób z niepełnosprawnością od działalności czysto komercyjnej, związanej ze sprzedażą na aukcjach i kiermaszach rękodzieła wykonywanego przez uczestników warsztatów terapii zajęciowej czy domów pomocy społecznej.

Wśród niczym niewyróżniających się aktów twórczych, mających ze sztuką niewiele wspólnego, można odnaleźć dzieła wybitne, zasługujące w pełni na miano sztuki (Makrzanowska 2005). Rodzi się więc pytanie o to, czy w społecznej świadomości niepełnosprawność i sztuka wzajemnie się wykluczają. Sztuka kojarzy się z doskonałością, a tę zwykliśmy przeciwstawiać niepełnosprawności. Czy doskonała sztuka może powstać mimo ograniczeń ułomnego umysłu? Stajemy tutaj przed paradoksem doskonałego dzieła i ułomnego twórcy. Doskonałość dzieł niepełnosprawnego twórcy można przyrównać do doskonałości malowideł z Lascaux ${ }^{1}$, zaskakujących swoją tajemnicą i siłą. Tym, co budzi zachwyt, nie jest doskonałość w rozumieniu perfekcji wykonania, ale niezwykła ekspresja, szczerość i nieskrępowana wyobraźnia. Obcując z nimi, przekonujemy się - jak zauważa Władysław Jurkow - „że sztuka jest obszarem wolnym od podziału na sprawnych i niepełnosprawnych" (Jurkow 2003, s. 6).

\section{Miejsce sztuki osób z niepełnosprawnością intelektualną}

Czy sztuce tworzonej przez artystów z niepełnosprawnością intelektualną nadaje się współcześnie odpowiednią rangę? Według Beaty Jaszczak „ta sztuka jest poza nurtem galeryjnym, poza nurtem opłacalności, aby ją promować. Nie łączy się z profitami finansowymi i innymi” (Jaszczak 2009, s. 38). Wciąż aktualny jest więc postulat jej dowartościowania i przyznania należytego miejsca w kulturze i świadomości społecznej (Zatorski 2011, s. 75). Jak stworzyć odpowiednie warunki do spotkania z dziełem niepełnosprawnego intelektualnie artysty możliwie jak największej grupie odbiorców? Jest to zadanie niezwykle trudne. Sztuka osób niepełnosprawnych często pozostaje w getcie ich środowiska (w ośrodkach, na warsztatach terapeutycznych, w domach pomocy społecznej, szpitalach). Wyjście artystów z niepełnosprawnością intelektualną z izolacji wymaga przełamywania barier i ograniczeń tkwiących zarówno w środowisku społecznym, jak i w samych osobach niepełnosprawnych i ich najbliższym otoczeniu (Rojek, Zatorski 2009, s. 65).

${ }^{1}$ Lascaux - jaskinia krasowa w Akwitanii, w południowo-zachodniej części Francji, w której w 1940 roku odkryto rysunki i malowidła wykonane na ścianach w okresie paleolitu. 
Zasadne jest więc podejmowanie działań upowszechniających sztukę osób z niepełnosprawnością intelektualną w taki sposób, aby zainteresować nią różne grupy społeczne, poszerzyć grono jej odbiorców, uczynić ją dostępną, przyjazną i rozpoznawalną. Promocji sztuki służą działania, dzięki którym instytucja promująca komunikuje się z odbiorcą. Polegają one między innymi na (Okrzeja 2009, s. 13):

- tworzeniu kolekcji dzieł sztuki i jej prezentacji szerokiej publiczności;

- inicjowaniu i rozpowszechnianiu wydarzeń artystycznych;

- zawiązywaniu się organizacji, fundacji i stowarzyszeń działających na rzecz promocji sztuki;

- organizacji konferencji, wykładów, prelekcji, eventów, festiwali;

- dbaniu o jakość kontaktu widza z dziełem sztuki;

- wspieraniu środowisk artystycznych.

Na polskiej mapie przedsięwzięć służących promocji sztuki osób z niepełnosprawnością intelektualną znajduje się bardzo wiele ciekawych inicjatyw. Wśród najważniejszych można wymienić działalność Stowarzyszenia Edukacyjno-Artystycznego „Oto ja” w Płocku, którego celem jest praca z artystami niepełnosprawnymi i chorymi psychicznie mieszkającymi w domach pomocy społecznej północnego Mazowsza, oraz działalność Galerii Tak w Poznaniu, istniejącej od 2002 roku w ramach Stowarzyszenia „Na tak”, która powstała, aby zajmować się współczesnymi, pomijanymi zjawiskami z obszaru kultury i sztuki. Lokalnie, na terenie Śląska, promocją sztuki spoza oficjalnego nurtu zajmuje się galeria Szyb Wilson, która od ośmiu lat jest organizatorem Art Naif Festiwal Międzynarodowego Festiwalu Sztuki Naiwnej, oraz Dział Plastyki Nieprofesjonalnej Muzeum Śląskiego w Katowicach pod kierownictwem Soni Wilk. Działalności Działu Plastyki Nieprofesjonalnej Muzeum Śląskiego w Katowicach w zakresie promocji i upowszechniania sztuki osób z niepełnosprawnością intelektualną poświęcę więcej uwagi, gdyż się wyróżnia i jest niepowtarzalna w skali Polski.

Przyjęło się, że pomijanymi oficjalnie zjawiskami sztuki i kultury zajmują się organizacje społeczne i prywatni kolekcjonerzy. Co więcej, muzea spotykają się z zarzutem, że pełnią w stosunku do sztuki rolę opresyjną. Theodor Adorno - filozof, teoretyk sztuki - w swojej krytyce muzeów podkreślał niebezpieczne funkcjonalne podobieństwa, jakie łączą muzea i mauzolea (mauzoleum-grobowiec) (Jodliński 2010). Działalność Działu Plastyki Nieprofesjonalnej Muzeum Śląskiego w Katowicach zaprzecza temu zarzutowi; wypełnia lukę i zaspokaja niedosyt sztuki spoza nurtu oficjalnego w państwowych placówkach kultury; swoim programem i dokonywanymi wyborami przeczy tezie, jakoby muzeum było instytucją martwą, niczym innym jak tylko przechowalnią zbiorów. Misją działu sztuki nieprofesjonalnej nie jest jedynie udostępnianie i przechowywanie dzieł artystów znanych, ale też tworzenie przestrzeni dla twórców mało znanych lub nieznanych w ogóle, dogłębne badanie oraz penetrowanie niezawodowych środowisk twórczych (Wilk, Plastyka... b.d.), również tych skupiających osoby niepełnosprawne intelektualnie. Muzeum Śląskie w Katowicach jako jedyna instytucja z Polski 
zostało wymienione w publikacji On the map. Exploring European Outsider Art, prezentującej najważniejsze europejskie muzea i galerie posiadające kolekcje sztuki intuicyjnej. W swoich zasobach ma prace najciekawszych reprezentantów polskiej sztuki nieprofesjonalnej.

Aby opisać działalność Działu Plastyki Nieprofesjonalnej w promocji szczególnych przedstawicieli sztuki samorodnej, jakimi są artyści niepełnosprawni intelektualnie, odwołam się do koncepcji kręgu promocyjnego Andrzeja Kostołowskiego (Kostołowski 2009, s. 5).

Rycina. Krąg promocyjny. Źródło: opracowanie własne na podstawie Kostołowski 2009.

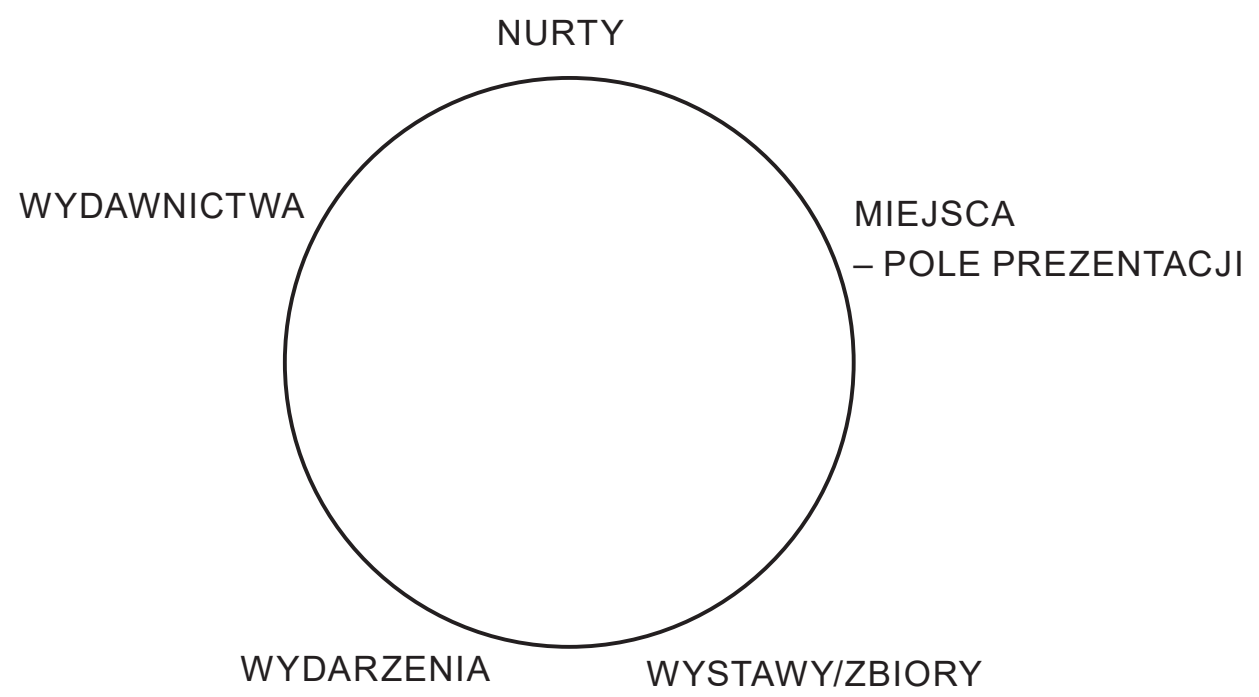

Na rycinie zaprezentowano pojęcia w układzie kolistym, co ilustruje równorzędność podejmowanych działań w zakresie promocji oraz ich wzajemnie uzupełnianie się. Okrąg pokazuje sprzężenie między sposobem działań promocyjnych a ich celem.

Nurty. Do jakiego obszaru można zaliczyć sztukę tworzoną przez osoby z niepełnosprawnością intelektualną? Władysław Jurkow, kurator wystawy w całości poświęconej malarstwu i rzeźbie osób z niepełnosprawnością intelektualną Oswajanie świata ${ }^{2}$, zauważa, że trudność z zaszeregowaniem ich twórczości wynika

2 Oswajanie świata to tytuł wystawy artystów niepełnosprawnych intelektualnie. Wystawa została przygotowana w 2003 roku w ramach obchodów Europejskiego Roku Osób Niepełnosprawnych przez Polskie Stowarzyszenie na rzecz Osób z Upośledzeniem Umysłowym przy współpracy z Centrum Sztuki Współczesnej Zamek Ujazdowski. Jej celem było przełamywanie barier społecznych i uprzedzeń w myśleniu o osobach z niepełnosprawnością intelektualną. 
z jej niezwykłego bogactwa i różnorodności (Jurkow 2003, s. 6). Każdy z artystów jest, cytując profesora Aleksandra Jackowskiego, osobny, inny (Jackowski 1995, s. 5). Sztukę tworzoną przez osoby z niepełnosprawnością intelektualną zwykło zaliczać się do obszaru zwanego art brut.

Art brut (ang. outsider art) sięga korzeniami początków XX wieku, kiedy twórcy zaczęli zwracać się do nowych źródeł i szukać inspiracji poza kanonem kultury śródziemnomorskiej (Jurkow 2003, s. 7). Dzięki nurtowi wyznaczonemu przez dadaistów, surrealistów, fowistów i ekspresjonizm niemiecki uformowała się nowa estetyczna wrażliwość, w ramach której zaczęto postrzegać w kategoriach artystycznych również dzieła twórców z pobocza kultury oficjalnej - wyobcowanych w szpitalach psychiatrycznych, więzieniach i przytułkach. Jednym z artystów, któremu sztuka osób wykluczonych była szczególnie bliska, był francuski malarz i rzeźbiarz Jean Dubuffet. To jemu zawdzięczamy określenie „art brut”, oznaczające sztukę surową, niezafałszowaną, samorodną, nieskażoną. Jest ona wolna od artystycznych i kulturowych szablonów, a jej twórcy nie wchodzą w dyskurs ze sztuką oficjalną (Wilk 2010, s. 4) (często po prostu jej nie znają z powodu ograniczeń kulturowych, fizycznych, psychicznych); malują tak, jak podpowiada im własna, niczym nieskrępowana wyobraźnia. „Tworzą pod wpływem impulsów wewnętrznych, «od środka»" - zauważa Aleksander Jackowski (Jackowski 1995, s. 5).

Miejsca - pola prezentacji. Dzięki miejscom - polom prezentacji, które, jak zauważa Jolanta Skutnik, spełniając wymogi nowej sztuki, traktują odwiedzającego jako współuczestnika aktu twórczego, mamy szansę wziąć udział w procesie emocjonalnego spotkania odbiorcy z twórcą (Skutnik 2008, s. 145). Uczestniczą oni w swoistym dialogu, obejmującym rzeczywistość sztuki, refleksję o niej, wkraczając we wspólny świat emocji i wrażeń. Polem prezentacji sztuki osób z niepełnosprawnością intelektualną w Muzeum Śląskim jest Galeria Sztuki Pogranicza oraz część nowej ${ }^{3}$ Galerii Plastyki Nieprofesjonalnej Art brut - Prezentacje. Miejsca te pulsują życiem, odbywają się w nich bowiem spotkania ze sztuką przywracające pamięć o twórcach zapominanych, upowszechniające twórczość mało znanych i odsłaniające dokonania tych, którzy nie są znani w ogóle, artystów „z nikąd”.

Galeria Sztuki Pogranicza prezentuje gromadzone od 1984 roku zbiory Działu Plastyki Nieprofesjonalnej. Sylwetki najciekawszych artystów art brut z intelektualnymi dysfunkcjami ukazywane są w cyklu wystaw Vivat insita. Do tej pory zaprezentowano w ten sposób twórczość Justyny Matysiak (jedynej polskiej laureatki Triennale w Bratysławie), Pawła Garncorza oraz Marii Wnęk.

Art brut - Prezentacje to z kolei wyodrębniona część Galerii Plastyki Nieprofesjonalnej, poświęcona w całości twórcom art brut. Wśród wielu na stałe wyeksponowanych prac znajdują się m.in. te autorstwa Pawła Garncorza.

326 czerwca 2015 r. otwarto nową siedzibę Muzeum Śląskiego. Jest to jedno z największych przedsięwzięć muzealnych w Polsce w ostatnich latach. Kompleks budynków muzealnych znajduje się na terenie dawnej kopalni węgla kamiennego w Katowicach. 
Wystawy/zbiory. Wystawy są najbardziej powszechną i najstarszą formą publicznej prezentacji sztuki. Celem ich organizacji jest stworzenie pola komunikacji między sztuką a jej odbiorcą. Powodzenie wystawy zależy głównie od założeń, wytyczonych celów i ambicji organizatorów. Peter Vergo zauważa, że dysponując określonymi dziełami sztuki, operując napisami, tablicami informacyjnymi, tekstami objaśniającymi, ustalając kolejność prezentacji dzieł, zasady, według których pogrupowane są dzieła, ale głównie poprzez kontekst skojarzeniowy można za każdym razem budować wystawą inną opowieść (Vergo 2006, s. 316). Osobą, która decyduje o sposobie tworzenia ekspozycji, począwszy od selekcji dzieł sztuki aż po katalog, jest kurator sztuki. O wystawie można więc powiedzieć, że staje się historią opowiedzianą poprzez dzieła sztuki zredagowaną przez kuratora, który staje się poniekąd współtwórcą wystawy (tamże).

Cykl wystaw pod wspólnym tytułem Vivat insita Muzeum Śląskie zainicjowało w 2009 roku. Ich kuratorką była Sonia Wilk, kierownik Działu Plastyki Nieprofesjonalnej. Cykl rozpoczęła wystawa Rysunki Justyny Matysiak (7 listopada 2009 - 17 stycznia 2010). Artystka od 2000 roku jest uczestniczką Warsztatów Terapii Zajęciowej Krzemień w Poznaniu. Od 2008 roku do dziś tworzy także w Otwartej Pracowni Galerii Tak. Jako jedyna Polka w 2007 roku otrzymała grand prix Insita, przyznane w ramach 8 . Triennale sztuki art brut/outsider art przez Słowacką Galerię Narodową w Bratysławie. Jej prace znajdują się w wielu międzynarodowych kolekcjach, m.in.: w Musée de la Création Franche w Bègles we Francji, Słowackiej Galerii Narodowej w Bratysławie, The Museum of Everything w Londynie, Muzeum Sztuki Współczesnej w Ołomuńcu, Państwowym Muzeum Etnograficznym w Warszawie, Muzeum Śląskim w Katowicach, Muzeum Etnograficznym w Krakowie i wielu kolekcjach prywatnych, m.in. Leszka Macaka w Krakowie (Justyna Matysiak... b.d.).

Osobowości i twórczości Justyny Matysiak poświęcony został rozdział Pokochaj mnie jak Pierre Cardin w książce pt. Twarze sukcesu. Zespół Downa. Dorota Starosta, kierowniczka Pracowni Działań Twórczych przy WTZ Krzemień, w rozmowie z autorką tekstu Izabelą Meyzą, opisuje nieskrępowaną wyobraźnię twórczą artystki: „W «Krzemieniu» Justyna tworzy od dziesięciu lat. Stworzyła tam cykl rysunków ze zwierzętami. Od pewnego czasu bardziej zajmują ją postacie. [...] Michel Jackson z brwiami jak chmury, koleżanka ze stolika obok z paznokciami w kolorach tęczy oraz wiele kobiet w naszyjnikach z pereł, z kolorowymi kolczykami w uszach, dłońmi, których palce przypominają pazury drapieżnych zwierząt, i grubymi nogami" (Meyza 2014, s. 116).

Sonia Wilk w folderze poświęconym wystawie artystki napisała: „Prace Justyny Matysiak urzekają wysmakowaną kolorystyką i ciekawą formą. Rysunki są wykonywane cienkopisem $z$ transparentnym tuszem. [...] Świat Justyny wciąga odbiorcę i wprawia w pogodny nastrój, nic zatem dziwnego, że jeden z największych teoretyków outsider art Roger Cardinal określił ją jako indywidualność twórczą o niesamowitym potencjale" (Wilk 2009). 
Idealny świat Pawła Garncorza jest kolejną wystawą z cyklu Vivat insita, na której przedstawiony został dorobek śląskiego artysty (8 lipca - 3 października 2010). Do twórczości plastycznej sprowokowała go terapia. Jego przygoda ze sztuką rozpoczęła się w pracowni szkoleniowo-rehabilitacyjnej prowadzonej przez Stowarzyszenie Wspierania Działań Twórczych Unikat w Katowicach, która została przekształcona w warsztaty terapii zajęciowej. Tam talent artysty zauważony został przez instruktora pracowni graficznej Piotra Zatorskiego. Ich wspólna artystyczna przygoda trwa do dziś. Obecnie Paweł Garncorz jest artystą samodzielnym (nie uczęszcza do żadnej zorganizowanej placówki), wspieranym przez Piotra Zatorskiego, który zajmuje się również promocją tej twórczości. Jego prace, jak zauważa Sonia Wilk w katalogu poświęconym wystawie, cechuje „wnikliwa obserwacja rzeczywistości i wręcz kronikarski sposób zapisu (rysunku) obserwowanego świata" (Wilk 2010, s. 5). Garncorz posiada wyjątkową łatwość przedstawiania skomplikowanych układów kompozycyjnych, które, jak zauważa Piotr Zatorski, „wprawiają w podziw niejednego profesjonalnego architekta" (Zatorski 2010). Szczególnym walorem prac artysty jest umiejętność budowania surrealistycznego nastroju, mimo realistycznej (wręcz hiperrealistycznej) formy.

Paweł Garncorz odnosi sukcesy artystyczne w dziedzinie sztuki nieprofesjonalnej. Ma za sobą szereg wystaw indywidualnych i zbiorowych oraz jest laureatem wielu nagród w konkursach przeznaczonych dla twórców nieprofesjonalnych.

Kolejnym pomysłem Działu Plastyki Nieprofesjonalnej na wystawę poświęconą twórczości artystów niepełnosprawnych intelektualnie była ekspozycja Sztuka czy terapia (18 marca - 4 maja 2014). Pokazane tam zostały prace plastyczne podopiecznych warsztatów terapii zajęciowej nagrodzone w konkursach regionalnych i ogólnopolskich. Część z nich pochodziła z konkursów przeznaczonych wyłącznie dla twórców z niepełnosprawnościami: Festiwalu Piosenki i Twórczości Osób Niepełnosprawnych w Tychach, Śląskiego Nieprzetartego Szlaku w Gliwicach czy jaworznickiej Magii Kolorów; w ramach wystawy prezentowane były również prace nagrodzone w konkursach otwartych: Ogólnopolskim Konkursie Malarskim im. Teofila Ociepki w Bydgoszczy oraz Konkursie Plastycznym dla Twórców Nieprofesjonalnych im. Pawła Wróbla w Katowicach, w których autor oceniany był jako samodzielny i pełnoprawny uczestnik życia artystycznego. Zamysłem wystawy było zwrócenie uwagi odbiorcy na pewną dychotomię, jaka pojawia się w twórczości osób z niepełnosprawnością intelektualną. Mamy dzieła wybitne, które jednak w dużej części powstają w procesie arteterapeutycznym. Nasuwa się zatem pytanie o priorytety i hierarchię ważności w twórczości osób z intelektualnymi dysfunkcjami. Wystawa jednak dobitnie pokazała, że granice między terapią a sztuką są płynne, a praca dobrego instruktora arteterapeuty może być wsparciem dla rozwoju talentu osoby z intelektualną niepełnosprawnością (Wilk Sztuka... b.d.).

Godnym zanotowania jest fakt, że oprócz organizowania wystaw poświęconych artystom z dysfunkcjami od 2008 roku tworzona jest w ramach zbiorów jedyna 
w Polsce spójna kolekcja muzealna prac najwybitniejszych polskich twórców nurtu art brut, w tym osób z niepełnosprawnością intelektualną. Są to z pewnością największe polskie zbiory sztuki, będące w posiadaniu instytucji kultury. Wśród zgromadzonych dzieł znajdują się prace m.in. Pawła Garncorza i Justyny Matysiak. Muzeum Śląskie posiada w swoich zbiorach również prace czołowych przedstawicieli nurtu art brut: Tadeusza Głowali (mieszkającego i tworzącego w Domu Pomocy Społecznej „Nad Jarem” w Miszewie Murowanym), Adama Dembińskiego (uważanego za jednego z najwybitniejszych twórców art brut w Polsce, mieszkańca DPS w Brwilnie, zmarłego w 2014 roku), Włodzimierza Mariana Rosłona (mieszkającego i tworzącego w Domu Pomocy Społecznej w Brwilnie), Grzegorza Sienkiewicza (uczestnika Warsztatów Terapii Zajęciowej w Haczowie), Krzysztofa Wiśniewskiego (mieszkającego i tworzącego w Domu Pomocy Społecznej w Brwilnie), Henryka Żarskiego (mieszkającego i tworzącego w Domu Pomocy Społecznej w Pakówce koło Leszna, zwanego Nikiforem z Pakówki); nie można też pominąć kolekcji prac autorstwa Nikifora i Marii Wnęk.

Wydarzenia. W ramach promocji sztuki osób z niepełnosprawnością intelektualną Muzeum Śląskie zorganizowało dwa znaczące wydarzenia, które przyczyniły się do innego spojrzenia na sztukę osób z intelektualnymi dysfunkcjami: konferencję „ONI - rola oraz aspekt artystyczny w twórczości osób niepełnosprawnych intelektualnie” (17 września 2010) oraz seminarium „Sztuka czy terapia”, dotyczące przejawów dyskryminacji osób z niepełnosprawnością intelektualną w sztuce (5 maja 2014).

Dzięki wymienionym wydarzeniom o charakterze popularyzatorskim i naukowym pokazano, w jaki sposób zmienia się współczesne pole interpretacji sztuki osób z niepełnosprawnością intelektualną. Zwrócono uwagę na niezwykłą dynamikę zjawiska art brut oraz na to, że twórczość osób z dysfunkcjami, w wyniku zmiany perspektyw, staje się sztuką właściwie na naszych oczach (Jodliński 2011, s. 9). Dzięki udziałowi w nich przedstawicieli pedagogiki specjalnej nakreślone zostały pedagogiczne konteksty i obszary twórczości osób z dysfunkcjami. Została również podjęta refleksja, w jaki sposób łączyć obie perspektywy i budować przestrzeń porozumienia między obszarem sztuki a obszarem pedagogiki w zakresie twórczości osób z niepełnosprawnością intelektualną. Zwrócono też uwagę na niebezpieczeństwa związane z twórczością osób z niepełnosprawnością, czyli przede wszystkim na zbytnią ingerencję $\mathrm{w}$ proces tworzenia instruktora i wynikające $z$ tego problemy z oceną oryginalności dzieła oraz kwestię łamania praw autorskich twórców niepełnosprawnych intelektualnie.

Wydawnictwa. Ich wkład w promocję twórczości powinien być zauważony i doceniony. Wydawnictwa są najbardziej trwałym w sensie materialnym elementem promocji, do którego potencjalny odbiorca sztuki może się wielokrotnie odnosić. Publikacje promujące sztukę osób z niepełnosprawnością intelektualną, których wydawcą było Muzeum Śląskie, dokumentują przede wszystkim wystawy czasowe organizowane przez Dział Plastyki Nieprofesjonalnej. Wystawie Justyny 
Matysiak poświęcony został zilustrowany pracami artystki i opatrzony komentarzem kuratora folder. Wystawie Świat idealny Pawła Garncorza towarzyszył katalog, opatrzony komentarzem rzucającym nowe światło na twórczość artysty autorstwa kuratorki Soni Wilk oraz Piotra Zatorskiego, mentora i promotora twórczości Garncorza.

W 2011 roku staraniem Muzeum Śląskiego ukazały się materiały z opisywanej wcześniej konferencji pt. ONI - rola oraz aspekt artystyczny w twórczości osób niepełnosprawnych intelektualnie. Jest to zbiór tekstów wygłoszonych w czasie konferencji, dotyczących zarówno wymiaru pedagogiczno-terapeutycznego, jak i artystycznego twórczości osób z intelektualnymi dysfunkcjami. Wśród osób autorów publikacji znaleźli się pedagodzy: prof. dr hab. Zenon Gajdzica (Uniwersytet Śląski, Wydział Etnologii i Nauk o Edukacji w Cieszynie), dr Grażyna Szafraniec (Uniwersytet Śląski, Wydział Pedagogiki i Psychologii w Katowicach), dr Anna Stawiarska (Akademia im. Jana Długosza w Częstochowie), etnolog, dr Grzegorz Odoj (Uniwersytet Śląski, Wydział Etnologii i Nauk o Edukacji w Cieszynie) oraz osoby związane ze sztuką: Małgorzata Szaefer (Galeria Tak w Poznaniu), Sonia Wilk (Muzeum Śląskie w Katowicach), Beata Jaszczak (stowarzyszenie „Oto ja” w Płocku), Piotr Zatorski (artysta, arteterapeuta, opiekun artystyczny Pawła Garncorza). Publikacja jest cennym przewodnikiem po świecie sztuki tworzonej przez osoby z niepełnosprawnością intelektualną. Wzbogacona reprodukcjami obrazów (m.in. Justyny Matysiak, Pawła Garncorza, Adama Dembińskiego, Henryka Żarskiego, Tadeusza Głowali) może przyczyniać się do innego, głębszego, bardziej refleksyjnego postrzegania sztuki osób z dysfunkcjami, dając wskazówki terapeutyczne instruktorom oraz stanowiąc inspirację dla osób profesjonalnie zajmujących się sztuką (kolekcjonerów, muzealników, kuratorów).

\section{Pełnosprawna sztuka. Zakończenie}

Narracje związane z twórczością osób z niepełnosprawnością w pedagogice specjalnej w swojej przeważającej części akcentują jej rehabilitacyjno-terapeutyczny wymiar. Dodając do każdej dziedziny sztuki słowo „terapia” (plastykoterapia, muzykoterapia, teatroterapia), zakłada się służebność sztuki wobec terapii, tym samym traktując twórczość jako narzędzie leczenia. Tymczasem chcemy promować sztukę osób z niepełnosprawnością intelektualną nie ze względu na jej wartość terapeutyczną, ale walor artystyczny. Dzięki działalności Działu Plastyki Nieprofesjonalnej Muzeum Śląskiego niepełnosprawny intelektualnie twórca jest ukazywany jako pełnoprawny członek świata kultury. Organizując wystawy indywidualne i zbiorowe, skupiając się na samorodnym talencie artysty, Muzeum Śląskie ukazuje twórcę jako podmiot w procesie tworzenia. Podejmowanie działań promujących sztukę osób z dysfunkcjami przyczynia się do przełamywania barier społecznych i krzywdzących stereotypów wobec osób z niepełnosprawnościami. 
Stwarza platformę do dyskusji, inicjując podejmowanie ważnych społecznie tematów dotyczących miejsca takich osób w społeczeństwie.

Podkreślając w powyższych rozważaniach fakt dysfunkcji intelektualnej artystów, chciałam pokazać, że osoba z niepełnosprawnością intelektualną jest częścią świata kultury i sztuki. Należy też pamiętać, że sztuka nie czyni rozróżnienia na artystów sprawnych i niepełnosprawnych; dysfunkcja przestaje mieć jakiekolwiek znaczenie. Wartością jest natomiast niepowtarzalność wyobraźni i emocji kreujących piękno. Wobec sztuki możliwe jest odejście od kategorii zbiorowych (sztuka osób niepełnosprawnych) i zwrot ku indywidualnym, niepowtarzalnym sylwetkom utalentowanych twórców.

\section{Bibliografia}

Gajdzica Z. (2011). O sztuce w życiu osób niepełnosprawnych. Kilka uwag z punktu widzenia pedagoga i pedagogiki. W: Rola oraz aspekt artystyczny w twórczości osób niepełnosprawnych intelektualnie. Materiały pokonferencyjne. Katowice: Wydawnictwo Muzeum Śląskiego.

Jackowski A. (1995). Sztuka zwana naiwna. Warszawa: Wydawnictwo Krupski i S-ka.

Jaszczak B. (2009). Kreatywność osób spoza kręgu kultury oficjalnej, w tym osób $z$ niepetnosprawnościa intelektualna i dysfunkcjami psychicznymi na przykładzie projektu „Oto ja”. W: Sochal B. Artyści niepetnosprawni w życiu społecznym i zawodowym. Materiały pokonferencyjne II Konferencji NIKIFORY. Warszawa: Fundacja Wspólna Droga.

Jodliński L. (2011). Słowo od Wydawcy. W: Rola oraz aspekt artystyczny w twórczości osób niepełnosprawnych intelektualnie. Materiały pokonferencyjne. Katowice: Wydawnictwo Muzeum Śląskiego.

Jodliński L. (2010). Słowo od Wydawcy. W: Świat idealny Pawła Garncorza. Katalog wystawy. Katowice: Wydawnictwo Muzeum Śląskiego.

Jurkow W. (2003). Oswajanie świata. Katalog wystawy. Warszawa: CSW - Zamek Ujazdowski.

Justyna Matysiak/CZARNE SERCE - artystka, dostępny na: http://galeriatak.pion. $\mathrm{pl} /$ justyna-czarna-artystka (otwarty 1.12.2015).

Kosakowski C. (2006). Twórczość osób z niepetnosprawnościa - wielość spojrzeń, wielość problemów. W: Baran J., Olszewski S. (red.). Świat pełen znaczeń. Kraków: Oficyna Wydawnicza Impuls.

Kostołowski A. (2009). Krag promocyjny (część pierwsza). „Zeszyty Artystyczne”, nr 18, dostępny na: http://za.uap.edu.pl/wp-content/uploads/2012/o2/ZeszytyArtystyczne-18.pdf (otwarty 1.12.2015).

Makrzanowska A. (2005). Trzy figurki każdego dnia. „Sztuka/Art”, nr 20.

Meyza I. (2014). Pokochaj mnie jak Pierre Cardin. W: Twarze sukcesu. Zespót Downa. Warszawa: Bardziej Kochani. 
Okrzeja A. (2009). Promocja sztuki współczesnej w obliczu praktyk kuratorskich. „Zeszyty Artystyczne”, nr 18, dostępny na: http://za.uap.edu.pl/wp-content/ uploads/2012/o2/Zeszyty-Artystyczne-18.pdf (otwarty 1.12.2015).

Pawlik S. (2012). Społeczne i kulturowe konteksty twórczości osób niepetnosprawnych intelektualnie. W: Stankowski A. (red.). Wspomaganie rozwoju. Konteksty edukacyjne - rewalidacyjne - resocjalizacyjne. Ružomberok: Verbum.

Rojek P., Zatorski P. (2009). Promocja sztuki osób z niepełnosprawnościa intelektualna na przykładzie Warsztatów Terapii Zajęciowej UNIKAT. W: Sochal B. (red.). Artyści niepetnosprawni w życiu społecznym i zawodowym. Materialy pokonferencyjne II Konferencji NIKIFORY. Warszawa: Fundacja Wspólna Droga.

Skutnik J. (2008). Muzeum sztuki wspótczesnej jako przestrzeń edukacji. Katowice: Wydawnictwo Uniwersytetu Śląskiego.

Vergo P. (2006). Milczacy obiekt. W: Popczyk M. (red.). Muzeum sztuki. Antologia. Kraków: Universitas (wydawnictwo elektroniczne).

Wilk S. Plastyka nieprofesjonalna, dostępny na: http://www.muzeumslaskie.pl/ zbiory-plastyka-nieprofesjonalna.php (otwarty 1.12.2015).

Wilk S. Sztuka czy terapia. Wystawa prac plastycznych podopiecznych warsztatów terapii zajęciowej nagrodzonych na konkursach regionalnych i ogólnopolskich, dostępny na: http://www.muzeumslaskie.pl/sztuka-czy-terapia-wystawa-prac-plastycznych-podopiecznych-warsztatow-terapii-zajeciowej-nagrodzonych-na-konkursach-regionalnych-i-ogolnopolskich.php (otwarty 1.12.2015).

Wilk S. (2010). Vivat insita. W: Świat idealny Pawła Garncorza. Katalog wystawy. Katowice: Wydawnictwo Muzeum Śląskiego.

Wilk S. (2009). Vivat insita. Rysunki Justyny Matysiak. Folder wystawy. Katowice: Wydawnictwo Muzeum Śląskiego.

Zatorski P. (2011). Ważniejsza wyobraźnia. W: Rola oraz aspekt artystyczny w twórczości osób niepetnosprawnych intelektualnie. Materialy pokonferencyjne. Katowice: Wydawnictwo Muzeum Śląskiego.

\title{
THE POSSIBILITY OF PRESENTING AND PROMOTING THE ART OF PEOPLE WITH INTELLECTUAL DISABILITIES
}

\begin{abstract}
The article shows that properly conducted exhibitions and educational activities can support the social inclusion of people with intellectual disabilities. In the article there are presented cultural institutions which, by means of disseminating and promoting the art of people with intellectual disabilities, change social perception of this group of people. The article presents the Department of Non-professional Art at Silesian Museum in Katowice as an example of an institution actively involved in promoting the artistic activity of people with intellectual disabilities.
\end{abstract}

Key words: intellectual disability, art, non-professional art, museum 
Sabina Pawlik - magister, asystent w Zakładzie Pedagogiki Specjalnej Wydziału Pedagogiki i Psychologii Uniwersytetu Śląskiego w Katowicach. Adres do korespondencji: Uniwersytet Śląski, Wydział Pedagogiki i Psychologii, Zakład Pedagogiki Specjalnej, ul. Grażyńskiego 53, 40-126 Katowice. Adres e-mail: sabinabroll@yahoo.com. 